\title{
The Cult of Maria Regina in Early Medieval Rome
}

\begin{abstract}
The iconography of Mary bearing the crown and vestments of a Byzantine empress has long been associated with the arts of the city of Rome, where the overwhelming majority of early examples survive. From the eighth century onwards, this theme was exploited by the popes to reinforce their claims to independence from secular authority. But did they invent it? This paper supports the view that the iconography was initially developed at the imperial court in Constantinople in the first half of the sixth century, and that it first appeared in Rome in an "imperial" as opposed to "papal" context.
\end{abstract}

Few cities in the Christian world can boast such a deep-rooted connection to the cult of Mary as can the city of Rome; and none can claim a longer history of depicting her in its art, stretching back in time to the early years of the third century in the Catacomb of Priscilla on the via Salaria. ${ }^{1}$ Indeed it would not be too outrageous to claim that the true patron saint of the Roman church is Mary, and not Peter or Paul. Of the many Marian images which have graced the city's churches over the past 1500 years or more, there is one iconographic type in particular which has come to be associated with Rome, and perhaps more specifically with the patronage of the papacy, and that is the image of Mary crowned as queen of heaven: usually known by the Latin epithet Maria regina. This phrase actually appears in the arts for the first time in a Roman context: flanking the head of Mary in a now sadly dilapidated mural formerly in the atrium of S. Maria Antiqua (Fig. 1), and datable to the reign of Pope Hadrian I (772-795), who appears with a square "halo" at the far left of the composition. ${ }^{2}$ Thus, from the very beginning, it would appear that the concept of Maria regina and the Roman papacy go hand in hand. Indeed, this linkage was first proposed some 80 years ago in a famous article by Marion Lawrence, ${ }^{3}$ and has subsequently been broadly accepted. This paper will examine the origins of the concept of Mary as queen, primarily although not exclusively in the visual arts. While accepting that Rome, and in par-

1. Klauser 1972; Russo 1979/1980-81; Osborne 2003; Thunø 2004. For the Catacomb of Priscilla: Bisconti 1996.
2. Rushforth 1902, 102-104; Wilpert 1916, 713-714, pl. 195; Tea 1937, 258-260; Osborne 1987, 194-196.

3. Lawrence 1925. 


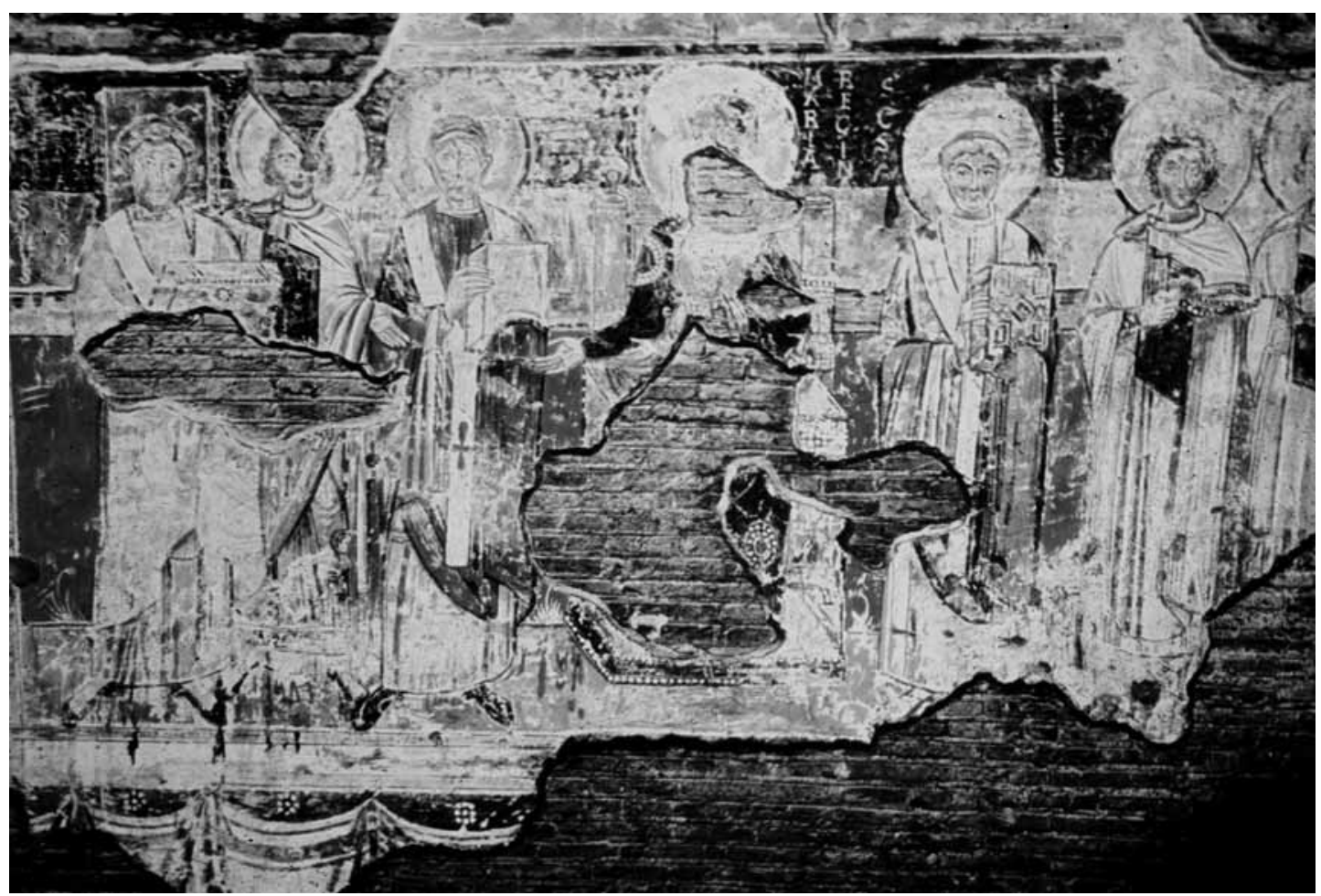

Fig. 1 - S. Maria Antiqua, Rome: Madonna and Child with saints and Pope Hadrian I (from Wilpert 1916, pl. 195).

ticular the papacy, embraced this iconography wholeheartedly and made it their own, it shall nonetheless be argued that the origins of the concept lay somewhere else, and most likely should be attributed to the imperial court in Constantinople. This conclusion, first proposed by Maria Andaloro, ${ }^{4}$ is the only one that appears consistent with the surviving evidence, scanty as that may be.

It was the fifth century - and specifically the Council of Ephesus in 431 which opened the door for more elaborate depictions of Mary in Christian art by designating her as theotokos, or "Mother of God". An early reflection of this new status may be found on the triumphal arch of the Roman church of S. Maria Maggiore, where for apparently the first time Mary is dressed in imperial court costume - not indicating the rank of an empress, but rather, as Beat Brenk has shown, that of a femina clarissima..$^{5}$ But it did not take long for her status to reach a higher level, and the primary evidence for this occurs first in words rather than images. By the early years of the sixth century, Mary's elevated rank was being celebrated in a variety of texts, including the hymns of Romanos the

4. Andaloro 1986.

5. Brenk 1975, 50. 
Melodos, and among them that most important of all Byzantine hymns to the Virgin, the Akathistos. ${ }^{6}$ Possibly the first Latin text to actually apply the word "regina" to Mary is the panegyric poem, In laudem Iustini Augusti minoris, written in Constantinople by the court poet Flavius Cresconius Corippus for the coronation of the emperor Justin II in 565. But the editor of this text, Averil Cameron, notes that the concept was not at all unusual in the Greek sources available to Corippus, and he does not seem to give it any special emphasis. ${ }^{7}$

With one - possibly two - exceptions, images of Mary with imperial dress and a crown are conspicuous by their absence until the beginning of the eighth century, at which point they make a dramatic and overwhelming appearance in the visual culture of papal Rome. There are at least seven Roman examples for which a dating to the eighth century is broadly accepted, and most of these can be specifically linked to the patronage of the pope or his court. Indeed, the two earliest are associated very specifically with Pope John VII (705-707). The first of these is the mosaic of the Virgin orans which formerly graced the funerary chapel of John VII in Old St Peter's, as recorded in the drawings of Jacopo Grimaldi in the early seventeenth century. The head of Mary with crown survived the demolition of Old St Peter's, and may be found today in the church of San Marco in Florence. ${ }^{8}$ The second example is the well-known icon of the Madonna della Clemenza in S. Maria in Trastevere, although its dating has been somewhat more controversial. ${ }^{9}$ John VII's devotion to the cult of Mary is widely attested, both in the inscriptions in his funerary chapel, as recorded by Grimaldi, and also in his other projects, including the bilingual inscription on the ambo which he installed in another Marian church that was very dear to him, S. Maria Antiqua. This refers to him as the servus sanctae Mariae - and in Greek as the doulos tes Theotokou. ${ }^{10}$ Indeed, John VII stands at the head of a long line of Roman pontiffs who would view themselves as the special servants of Mary. ${ }^{11}$ Another in the early ninth century would be Pope Paschal I (817-824), who depicts himself in an act of obeisance, holding her slipper, in the apse mosaic of S. Maria in Domnica.

In the aftermath of John VII's brief reign, images of Mary as regina abound in eighth-century Rome. These include two murals in the church of S. Maria Antiqua in the Roman Forum: one in the Theodotus chapel, datable to the reign of Pope Zacharias (741-752), and the second in the atrium, datable to the reign of Hadrian I (772-795). The latter is the example in which the phrase "Maria regina" appears in art as a painted inscription for the first time, although the use of these actual words may be found a decade or two earlier in a carved inscription located in the narthex of S. Maria in Cosmedin, recording the devotion of a member of the Roman nobility, the dux Eustathius. ${ }^{12}$ The term "regina" is additionally applied to Mary in the

6. Wellesz, 1956; Limberis 1994, 89-97, 149-158.

66-70, 148-159.

7. Corippus 2:52-53; Cameron 1978, 85.

8. Nordhagen 1965, 124-127.

10. Rushforth 1902, 89-91.

9. Bertelli 1961; Andaloro 1972-73; Kinney 1975

11. Deshman 1989.

12. Gray 1955, 55; Arena et al., 112. 
early ninth century in the inscription on the enamel cross of Paschal I, formerly in the Sancta Sanctorum at the Lateran, and now in the Vatican Museum. ${ }^{13}$ Also generally assigned to the eighth century, although without precise dates, are three other examples: the mural which survives in the niche in the right aisle of the lower church of San Clemente; ${ }^{14}$ a mural discovered in the mid nineteenth century in S. Lorenzo fuori le mura, subsequently destroyed, but fortunately recorded both in photographs and in a watercolour copy, the latter now in the Raccolta Lanciani in the Palazzo Venezia (Fig. 2): ${ }^{15}$ and finally the mural discovered in 1991 in fragments beneath the floor of S. Susanna, and recently reconstituted. ${ }^{16}$ There is no doubt that images of Mary as queen or empress enjoyed widespread popularity in Rome from the eighth century onwards. The theme would become particularly prominent again in the twelfth century, in the St Nicholas Chapel in the Lateran palace, ${ }^{17}$ and in the apse mosaics of S. Maria in Trastevere and S. Francesca Romana. The political significance of these later examples has been amply studied by Ursula Nilgen, Mary Stroll and others, and need not be repeated here. ${ }^{18}$ Rather, the present paper will examine the origins of this iconographic type.

The one earlier Roman example, left aside from the discussion thus far, is one of the best known to modern scholars of Marian iconography: the image of the enthroned Madonna and Child in S. Maria Antiqua in the Roman Forum (Fig. 3). This image belongs to the lowest level of figural paintings on the so-called palimpsest wall, located to the right of the apse -- and indeed it pre-dates the creation of that apse, which was carved out of a solid wall. ${ }^{19}$ In the process of creating the apse, the portion of the wall with the original left-hand side of this mural was lost, presumably necessitating the complete re-painting of the palimpsest wall. This was done with another Marian theme, the Annunciation.

What can we say about the date of this early Maria regina mural and the circumstances of its patronage? Clearly it must have been painted before the middle of the seventh century, which is a highly plausible date for the third level of murals painted on the palimpsest wall. The third level depicts figures of theologians, holding scrolls with lengthy Greek texts, and the latter have been demonstrated as bearing particular significance to the deliberations of the Lateran synod of 649, which condemned as heresy the doctrine of monotheletism. ${ }^{20}$ And it is probably not unreasonable to assume that the Maria regina may be considerably earlier than circa 650, given that there is an intervening stage of decoration, namely the second level with the Annunciation. That second level is usually associated -- and not implausibly -- with the general restructuring of the Domitianic hall for use as a formal site of Christian cult practice. ${ }^{21}$ This reno-

13. Thunø 2002, 25, 28-29.

14. Osborne 1981.

15. Muñoz 1944, pl. 89.

16. Andaloro 2001; Nilgen 2002.

17. Osborne and Claridge 1996, 108-111.
18. Nilgen 1981; Stroll 1997.

19. Rushforth 1902, 67; Nordhagen 1962, 56-57.

20. Rushforth 1902, 68-73; Nordhagen 1962, 58-61; Nordhagen 1978, 97-99.

21. Nordhagen 1962, 57-58. 

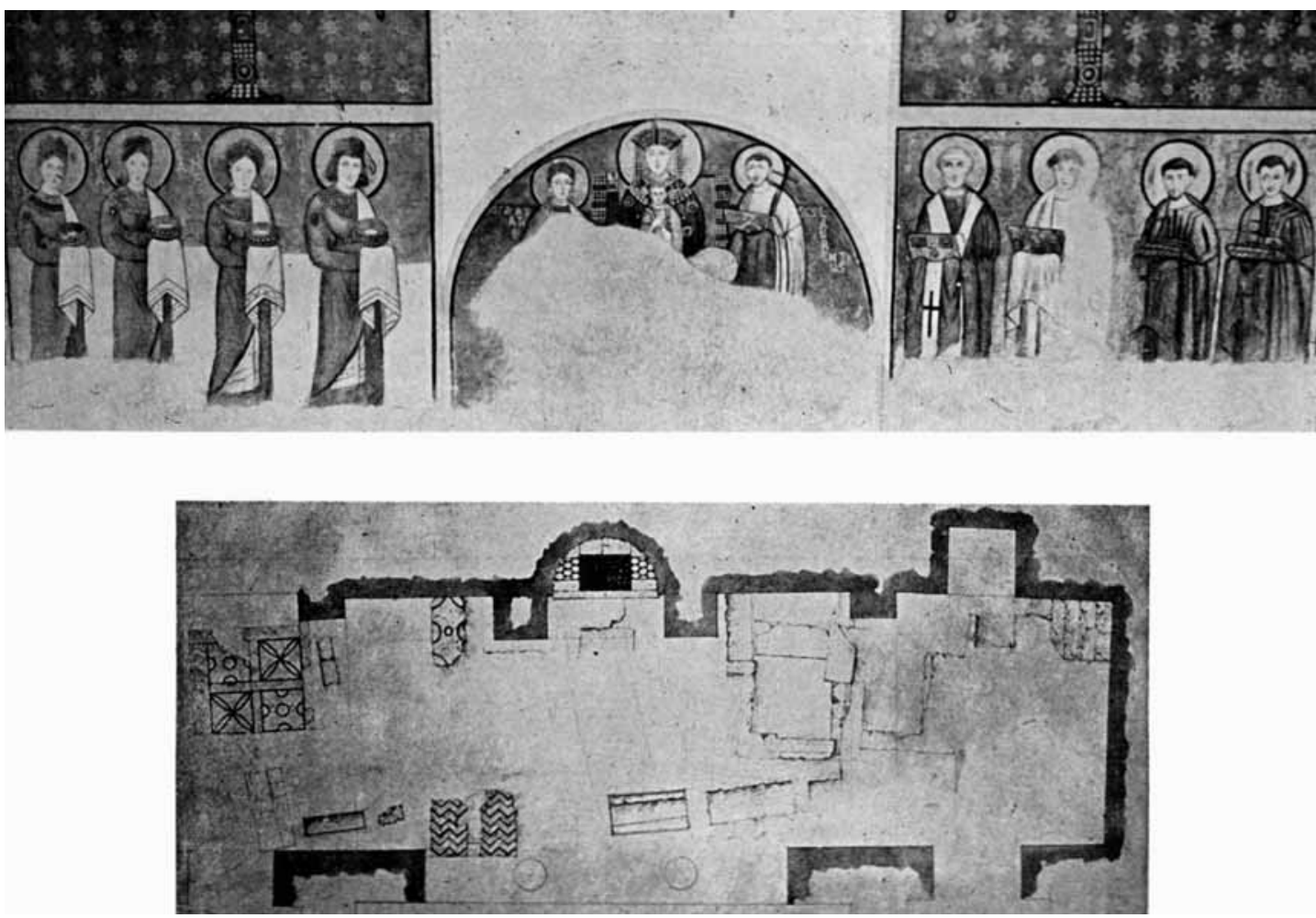

FIG. 2 - S. Lorenzo fuori le mura, Rome: copy of mural formerly in east aisle niche (from Muñoz 1944, pl. 89).

vation of the building included the creation of an apse in the thickness of the back wall, and also the replacement of some of the brick piers with columns, creating an interior space resembling that of a basilica church. For the date of this architectural conversion, much depends on the supposed discovery by the excavator, Giacomo Boni, of a coin or coins datable to the reign of the Byzantine emperor Justin II (565-578) beneath one of the new columns. This would suggest the third quarter of the sixth century as a plausible date for these alterations. While some have doubted that these coins ever existed, there is no particular need to discredit this telling evidence, first published in 1937 by Eva Tea ${ }^{22}$-- and elsewhere I have suggested that the coins of Justin II, found by Richard Reece in a box in the Palatine Antiquarium labelled "Fonte di Giuturna", may well be the ones in question. ${ }^{23}$ If the formal conversion of the building to a church may be posited sometime in the second half of the century, then this would push the first level of the palimpsest wall, and our earliest Maria regina back to the mid

22. Tea 1937, 19, 362; Krautheimer et al. 1962, 254- $23 . \quad$ Osborne 1987, 188-189. 255; Wright 1975, 16-17. 


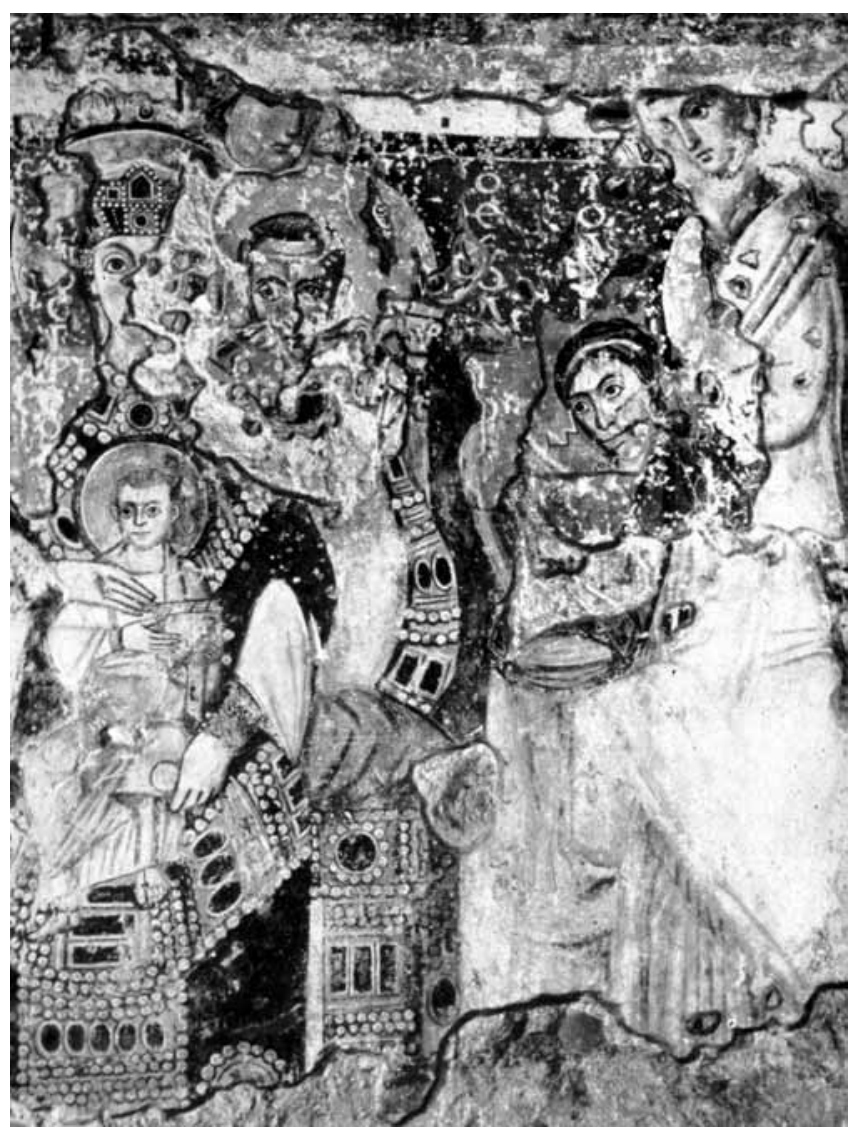

FIg. 3 - S. Maria Antiqua, Rome: palimpsest wall with Maria regina (author's archive).

century or earlier, probably to the reign of Justinian (527-565). Of course there can be no air of absolute certainty, but this dating in the first half of the sixth century has found favour with most of those scholars who have been interested in S. Maria Antiqua, including Per Jonas Nordhagen. The execution of the mural would thus roughly coincide with the Byzantine texts which also envisage Mary as queen of heaven.

What does this tell us? Regardless of the precise date, the following points appear to be incontrovertible. One: the Maria regina on the palimpsest wall is considerably earlier than all the other known Roman examples of this iconography, and probably in the order of 150 years earlier, plus or minus. Two: it could not have served as a model for the numerous eighth-century examples of this theme, since it was subsequently covered by the layer containing the mural of the Annunciation, and thereafter hidden from view until the excavation of the site by Boni in 1900. The S. Maria Antiqua mural thus stands apart from the 
large group of Maria regina images from the eighth and later centuries, a group for which the patronage may be linked very securely to the papal court.

The obvious question is this: what do we know about the patronage of that first early image in S. Maria Antiqua? Here the ground is considerably less firm, but there is no reason to suspect that this site in the Roman Forum was in any way related to the Roman church or its clergy before the mid seventh century, in the aftermath of the Lateran synod. Indeed, given the location of S. Maria Antiqua, and its obvious physical proximity to whatever remained of the imperial palace on the Palatine -- to which it was, and still is, connected by the Palatine ramp -- it is much more plausible to think of this space in terms of the imperial administration rather than the papacy, a point that has been argued very cogently by Andrea Augenti. ${ }^{24}$ And the choice of the Maria regina iconography is even more plausible in this context if we think in terms of its possible origins in the court circles in Constantinople, from which officials such as Belisarius, Narses, and others came to undertake the reconquest of Italy from the Ostrogoths, and subsequently to rule as exarchs. While the principal seat of imperial administration may have been situated in Ravenna, the imperial palace in Rome was certainly maintained well into the seventh century. The Emperor Constans II probably resided there during his twelve-day visit to Rome in $663,{ }^{25}$ and the funerary epitaph of Plato, father of Pope John VII, formerly in the nearby church of S. Anastasia, reveals him to have been the official caretaker of the palace. ${ }^{26}$ This goes a long way to explain John's interest in this particular site, and his somewhat curious decision to remove the papal residence from the Lateran to a new episcopium on the Palatine. ${ }^{27}$

Quite apart from the link between the site of S. Maria Antiqua and the imperial administration in Rome, the visual manifestation of the Maria regina iconography can similarly be linked to the imperial court. Empresses did not always wear purple robes nor sport jewelled crowns. Indeed, as Diliana Angelova has recently pointed out, our familiar image of the Byzantine empress, as known from examples such as the mosaic depicting the Empress Theodora in S. Vitale at Ravenna, does not have ancient roots - nor was it static. This image evolved principally in the fifth century, to judge from the representations of empresses on coins and ivories. But it was only in the sixth century that, as Angelova puts it, "the imperium was conceived as a partnership of a male and female sovereign", which is also the political thinking that makes possible the depiction of Mary as queen..$^{28}$

A possible further indication of the apparent discontinuity between our earliest Maria regina, in S. Maria Antiqua, and subsequent Roman examples from the eighth century and later, may perhaps be found in a survey of Marian

24. Augenti 2000, 50-51.

25. Liber pontificalis 1:343-344.

26. Liber pontificalis 1:386.
27. Liber pontificalis $1: 385$.

28. Angelova 2004. 
images from the intervening years -- not that there are many. However, there do exist a number of painted icons which are generally considered to belong to this period, including the icon from the Pantheon, which is often linked to the conversion of that building into a Christian church by Pope Boniface IV, or the icon now in S. Francesca Romana, believed by many to have been transferred to this location in the mid ninth century when S. Maria Nova was built to replace S. Maria Antiqua. ${ }^{29}$ Of more secure date is the mosaic in the apse of the San Venanzio chapel in the Lateran baptistery, constructed by Pope John IV (640-642) to house the relics of the Dalmatian martyrs. ${ }^{30}$ Mary appears in their midst as an orant, but there is no indication of imperial status, and no crown. It would be most useful to have some indication of the appearance of Mary in the images brought back from Rome to England by Benedict Biscop in the late years of the seventh century. The various items acquired on a series of "shopping trips" to Rome are described by Bede in his Historia abbatum, and presumably he would have seen these himself in the monasteries of Monkwearmouth and Jarrow -- but sadly he states only that these "picturas" of holy figures and of sacred history included images of Mary and of the twelve apostles, without specifying precisely how Mary was portrayed. ${ }^{31}$ Incidentally, a useful confirmation of the plausibility of such shopping expeditions by Benedict Biscop and others has been provided by the excavations at the Crypta Balbi, which reveal that Rome in the seventh century was an important source of industrial production, serving a broad international market. Certainly there can be no doubt that Roman artists of the seventh century could have depicted Mary as empress had their patrons so wished, as they had no difficulty in showing other figures in imperial court dress -- and a good example is provided by the figure of St Agnes in the apse mosaic from her shrine church on the Via Nomentana. This can be dated to the pontificate of Honorius I (625-638), who is credited by the Liber pontificalis with its construction, as well as being named in the apse inscription. ${ }^{32}$

Thus, despite the enormous popularity which the concept of Mary as queen enjoyed in Rome from the eighth century onwards, indeed to the point that it became almost a symbol for the papacy and for its independence from secular political authority, ${ }^{33}$ there is no compelling evidence to support Lawrence's claim that the iconography of the Maria regina had its origins in Italy. Rather, those origins should more plausibly be placed at the imperial court in Constantinople, which is where the idea first emerges in written texts, and where the regalia of the empress develops over the course of the fifth and early sixth centuries. That the earliest surviving example of a Maria regina should survive in Rome, on the palimpsest wall in S. Maria Antiqua, is probably quite accidental - and even in

29. Amato 1988; Andaloro 2002.

30. Mackie 1996.

31. Meyvaert 1979.
32. Liber pontificalis 1:323, 325.

33. Belting1987, 14-15; Noble 2001, 66. 
that instance the patronage should be thought of as imperial, rather than papal. In the sixth century it was the imperial court that constituted the principal force promoting the cult of Mary, not the popes - and a number of imperial couples are recorded as having taken a personal interest in promoting her Constantinopolitan shrines of Blachernai and Chalkoprateia, both of which were founded by the empress Verina, consort of Emperor Leo I, in the early 470s. ${ }^{34}$

No discussion of this question can ignore entirely a second possible early example of the Maria regina iconography, this one located not in Rome but on the wall of a chapel built into the Roman amphitheatre at Durrës in Albania (ancient Dyrrachium). ${ }^{35}$ Although published originally as an image of Christ, most of those who have observed the central figure in the mosaic on the side wall of the chapel consider it to be an image of Mary, an identification which has been argued for by Robin Cormack and Maria Andaloro, among others. ${ }^{36}$ The date of the Durrës amphitheatre chapel is not at all secure, but from the points of view of both style and technique by far the best comparisons are to be found in mosaics from the church of St Demetrios in Thessaloniki, dating from roughly the year 600. Thus we may have in Durrës another early example of a Maria regina, and once again one not to be associated with the Roman papacy. But until issues of identification, date and patronage can be more fully resolved, it is difficult to make much use of this evidence.

The final question to be posed is whether it is also plausible, or even possible, that Pope John VII could have been responsible for re-introducing to Rome a Marian iconographic type not then current in the city. The answer to this must surely be a resounding affirmative. Roman interest in Mary appears to have picked up demonstrably towards the close of the seventh century. An important step was taken by Pope Sergius I (687-701), perhaps significantly another pope of eastern origin, who is credited in the Liber pontificalis with having introduced into the Roman stational liturgy a litany procession on three of the principal Marian feasts - those of her Nativity, the Annunciation and the Dormition. ${ }^{37}$ The moment was thus ripe for a substantial revival of interest in depicting her image. Where John VII found his painters and mosaicists is not known, and this topic remains the subject of considerable conjecture - although the recent analysis of the composition of various plasters in S. Maria Antiqua, which demonstrates that the team of mural painters working for John VII was employing a technique for plaster not hitherto used in Rome, is very suggestive in that regard. ${ }^{38}$ There can be no doubt whatsoever that John VII was a great innovator in terms of the subject matter displayed on the walls of Roman churches, as Nordhagen and others have shown on numerous occasions. For example, he may have been

\footnotetext{
34. Cameron 2000, 12-13; Mango 2000.

35. Thierry 1968.

36. Cormack 1985, 84; Andaloro 1986; Pace 2003, 96-110.
}

37. Liber pontificalis 1:376.

38. Werner Schmid, personal communication, 1 June 2004. 
the first to introduce to Roman painting the use of the so-called "square halo" to signify portraits, a concept which certainly has its origins in the Christian East and which may be found in the donor portraits in the mid sixth-century apse mosaic at the Monastery of St Catherine's at Mount Sinai, a century and a half before it appears in Rome at S. Maria Antiqua and in John VII's funerary chapel in old St Peter's. ${ }^{39}$ Could the depiction of Mary as regina be another for that list? Could it have been an image first invented and promoted by the imperial court in Constantinople, to which John VII, a Greek-speaking pontiff who was the son of an imperial administrator, had very close links? Certainly the images and texts which survive from John's patronage activities leave us in little doubt regarding his total devotion to the Mother of God. Could the Maria regina have been an image which in Byzantium proper simply did not survive a century or more of imperial patrons who fervently opposed any use of religious images? The evidence points very strongly in this direction.

\section{John Osborne}

Faculty of Arts and Social Sciences,

Carleton University,

Ottawa, ON

Canada K1S $5 B 6$

[john_osborne@carleton.ca]

39. Osborne 1979. 


\section{BIBLIOGRAPHY}

Amato P. 1988: De Vera Effigie Mariae: Antiche Icone Romane, Rome.

Andaloro M. 1972-73: "La datazione della tavola di S. Maria in Trastevere", Rivista dell'Istituto Nazionale d'Archeologia e Storia dell'Arte 19-20, 139-215.

Andaloro M. 1986: "I mosaici parietali di Durazzo o dell'origine costantinopolitana del tema iconografico di Maria Regina", in O. Feld and U. Peschlow (eds.) Studien zur spätantiken und byzantinischen Kunst: Friedrich Wilhelm Deichmann gewidmet, Bonn, 3:103-112.

Andaloro M. 2001: "S. Susanna. Gli affreschi frammentati”, in M. Arena et al. (eds.) Roma dall'Antichità al Medioevo: Archeologia e Storia, Milan, 643-645.

Andaloro M. 2002: "Le icone a Roma in età preiconoclasta”, Roma fra Oriente e Occidente (Settimane di Studio XLIX), Spoleto, 719-753.

Angelova D. 2004: "The ivories of Ariadne and ideas about female imperial authority in Rome and early Byzantium", Gesta 43, 1-15.

Arena M. et al. 2001: Roma dall'Antichità al Medioevo: Archelogia e Storia, Milan.

Augenti A. 2000. "Continuity and discontinuity of a seat of power: the Palatine hill from the fifth to the tenth century", in J. Smith (ed.) Early Medieval Rome \& the Christian West: Essays in Honour of Donald A. Bullough, Leiden, 43-53.

Belting H. 1987: "Papal artistic commissions as definitions of the medieval church in Rome", in H. Hager and S. Scott Munshower (eds.) Light on the Eternal City. Observations and Discoveries in the Art and Architecture of Rome, University Park PA, 13-29.

Bertelli C. 1961: La Madonna di S. Maria in Trastevere, Rome.

Bisconti F. 1996: "La Madonna di Priscilla: interventi di restauro ed ipotesi sulla dinamica decorativa”, $R A C r$ 72, 7-34.

Brenk B. 1975: Die frühchristlichen Mosaiken in S. Maria Maggiore zu Rom, Wiesbaden.

Cameron A. 1978: "The Theotokos in sixth-century Constantinople", Journal of Theological Studies 29, 79-108.

Cameron A. 2000: "The early cult of the Virgin", in M. Vassilaki (ed.) Mother of God. Representations of the Virgin in Byzantine Art, Milan, 3-15.

Cormack R. 1985: Writing in Gold: Byzantine society and its icons, London.

Corippus: In laudem Justini Augusti minoris, A. Cameron (ed.), London, 1976.

Deshman R. 1989: "Servants of the Mother of God in Byzantine and medieval art", Word \& Image 5, 33-70.

Gray N. 1955: "The paleography of Latin inscriptions in the eighth, ninth and tenth centuries in Italy", BSR 16, 38-162.
Kinney D. 1975: "S. Maria in Trastevere from its founding to 1215 ”, Ph.D. diss., New York University, New York.

Klauser T. 1972: "Rom und der Kult der Gottesmutter Maria”, JbAC 15, 120-135.

Krautheimer R. et al. 1962: "S. Maria Antiqua", in Corpus basilicarum christianarum Romae, Vatican City, 2: 249-268.

Lawrence M. 1925: "Maria Regina”, ArtB 7, 150-161.

Liber pontificalis, L. Duchesne (ed.), Paris, 1886-1892.

Limberis V. 1994: Divine Heiress. The Virgin Mary and the Creation of Constantinople, London

Mackie G. 1996: "The San Venanzio Chapel and the martyr shrine sequence", RACAR 23: 1-13.

Mango C. 2000: "Constantinople as Theotokoupolis", in M. Vassilaki (ed.) Mother of God. Representations of the Virgin in Byzantine Art, Milan, 16-25.

Meyvaert P. 1979: "Bede and the church paintings at Wearmouth-Jarrow”, Anglo-Saxon England 8, 63-77.

Muñoz A. 1944: La basilica di S. Lorenzo fuori le mura, Rome, Rome.

Nilgen U. 1981: "Maria Regina -- ein politischer Kultbildtypus?”, Römisches Jahrbuch für Kunstgeschichte 19, $1-33$.

Nilgen U. 2002: "Eine neu aufgefundene Maria Regina in Santa Susanna, Rom”, in K. Möseneder and G. Schüssler (eds.) "Bedeutung in den Bildern": Festschrift für Jörg Traeger zum 60. Geburtstag, Regensburg, 231-245.

Noble T. 2001: “Topography, celebration and power: the making of a papal Rome in the eighth and ninth centuries", in M. de Jong and F. Theuws (eds.) Topographies of Power in the Early Middle Ages, Leiden, 45-91.

Nordhagen P.J. 1962: "The earliest decorations in Santa Maria Antiqua and their date", ActaAArtHist 1, 53-72.

Nordhagen P.J. 1965: “The mosaics of John VII (705-707 A.D.)", ActaAArtHist 2, 121-166.

Nordhagen P.J. 1978: "S. Maria Antiqua: the frescoes of the seventh century", ActaAArtHist 8, 89-142.

Osborne J. 1979: "The portrait of Pope Leo IV in San Clemente, Rome: a re-examination of the so-called 'square' nimbus in medieval art', BSR 47, 58-65.

Osborne J. 1981: "Early medieval painting in San Clemente, Rome: The Madonna and Child in the Niche", Gesta 20, 299-310.

Osborne J. 1987: “The atrium of S. Maria Antiqua, Rome; a history in art", BSR 55, 186-223.

Osborne J. 2004: "Images of the Mother of God in Early Medieval Rome”, in A. Eastmond \& L. James (eds.) Icon \& Word. The Power of Images in Byzantium, Aldershot, 135-156.

Osborne J. and Claridge A. 1996: Early Christian and Medieval Antiquities. 1: Mosaics and Wallpaintings in 
Roman Churches (The Paper Museum of Cassiano dal Pozzo, Series A, Part II-1), London.

Pace V. 2003: "Mosaici e pittura in Albania (VI-XIV secolo). Stato degli studi e prospettive di ricerca", Antichità Altoadriatiche 53: 93-128.

Rushorth G. 1902: "The church of S. Maria Antiqua", BSR 1, 1-123.

Russo E. 1979/1980-81: "L'affresco di Turtura nel cimitero di Commodilla, l'icona di S. Maria in Trastevere e le più antiche feste della Madonna a Roma”, Bullettino dell'Istituto Storico Italiano per il Medio Evo e Archivio Muratoriano 88/89, 35-85; 71-150.

Stroll M. 1997: "Maria Regina: Papal Symbol”, in A. Duggan (ed.) Queens and Queenship in Medieval Europe, Woodbridge, 173-203.
Tea E. 1937: La Basilica di Santa Maria Antiqua, Milan. Thierry N. 1968: "Une mosaïque à Dyrrachium", CArch $18,227-229$.

Thunø E. 2002: Image and Relic. Mediating the Sacred in Early Medieval Rome, Rome.

Thunø E. 2004: "The Cult of the Virgin, Icons and Relics in Early Medieval Rome", ActaAArtHist 17, 79-98.

Wellesz E. 1956: “The 'Akathistos': a study in Byzantine hymnography”, DOP 9-10, 141-174.

Wilpert J. 1916: Die römischen Mosaiken und Malereien der kirchlichen Bauten vom IV. bis XIII. Jahrhundert, Freiburg im Breisgau.

Wright D. 1975: "The shape of the seventh century in Byzantine art", Byzantine Studies Conference. Abstracts of Papers 1, 9-28. 